\title{
Change Management in the Governance of Schooling: The Rise of Experts, Planners, and Statistics in the Early OECD
}

\author{
DANIEL TRÖHLER \\ University of Luxembourg
}

\begin{abstract}
Background/Context: Based on archival material, the following paper analyzes the political strategies of the early OECD stakeholders in transforming schooling from a cultural to a technological system and how they were in need of standardizing different existing patterns of thoughts or institutional behaviors in the member countries. The European standardization process observable in the early 1960s, triggered by the OECD, affected the organization of the educational policies on a ministerial level designed to influence the national school systems according to a specific ideology.
\end{abstract}

Purpose: The paper asks how this new managerial ideology was transported, disseminated, and implemented and finds its answer in a specific rhetoric that bypassed politically taboo themes and that covered up the clear strategies: The new iron cage of accountability was based on omitting controversial topics.

Research Design: A contextual reconstruction of the discourse emerging from and reinforcing the process of standardization and the dissemination of specific ways of educational planning, such as statistics, and with them specific ideologies of how society and its citizens should be shaped.

Conclusions/Recommendations: Revisiting today's educational bureaucracy and its logic of expertise, standards, and accountability by reconstructing its origins in the Cold War and by that challenging the ideology of uniformity and accepting plurality as the condition of life of late modern societies.

Traditionally, the Cold War is understood as a continuous political and military tension between two global powers, the West, dominated by the United States with its allies organized in the North Atlantic Treaty Organization (NATO), and the East, dominated by the Soviet Union with its allies organized in the Warsaw Pact. Whereas this traditional view has been focusing on the conflicts and proxy wars around the world, scholars have-foremost after the end of the Cold War in 1989—-started to examine the intended and unintended domestic effects of the Cold War in politics, science policy, culture, and education (Evans, 2011; Fousek, 2000; Gilman, 2003; Hartman, 2008; Leslie, 1993; Rudolph, 2002; Solovey, 2013; 
Urban, 2010): The Western ideals of the Cold War were not simply for decades handed down and defensible ideals but subject to changes towards specific ideals or systems of reasoning that had been dominant in concrete models of successful cooperation between policy, science, and technological innovation during the Second World War.

These new ideals or systems of reasoning were not in any case simple developments of the older, traditional ideals about national coexistence, democracy, and justice, but sometimes quite opposed to them, and it usually took shocking events such as the Korean War (1950-1953) or the launch of the Soviet satellite Sputnik (1957) to help these new ideas little by little to be more broadly implemented within the traditional culture-and by that transforming it. These new ideals or systems of reasoning also affected, among other ideas, education, which henceforth was made accountable in a specific way to serve these new ideals. This process of making education accountable involved a change towards standardization, centralization, and scientification in education that was, up to then, rather foreign to the traditional way of the local organization and local control of education.

Standardization, centralization, and scientification of education became visible foremost after Sputnik, but it was already laid out in the epitome of the new ideology, in the Vannevar Bush's Report to the President in 1945, called the Endless Frontier (Bush, 1945). ${ }^{1}$ In 1944, Bush had been asked by President Roosevelt to prepare a report on (among others) the following question: "What can be done, consistent with military security, and with the prior approval of the military authorities, to make known to the world as soon as possible the contributions which have been made during our war effort to scientific knowledge?" (Bush, 1945). This question was of utmost importance for it asked that strategies developed during wartime be applied in peacetime. Bush's report related the future fight against diseases, defense against aggressors, and the establishment of a welfare state closely to "new knowledge" that "can be obtained only through basic scientific research" (Bush, 1945, section Summary of the Report), and doing science meant a teamwork of experts, exactly as it had been practiced during the Second World War-efficient cooperation, developed during the war, is irrelevant of war or peace, but dependent on the progress of science: "Science can be effective in the national welfare only as a member of a team, whether the conditions be peace or war. But without scientific progress no amount of achievement in other directions can insure our health, prosperity, and security as a nation in the modern world" (Bush, 1945a). Evidently, science education as a program for the "renewal of our scientific talent" (Bush, 1945, Chapter 4) was of the highest importance for the future, and thus the future of the nation becomes a question of educational policy. Vannevar Bush quotes in his report his friend James 
B. Conant, the President of Harvard University and at the time also head of National Defense Research Committee, NDRC: "So in the last analysis, the future of science in this country will be determined by our basic educational policy" (Bush, 1945, Chapter 4).

However, when Sputnik was launched on 4 October 1957 the Cold War became thoroughly educationalized (Martens \& Wolf, 2009, p. 365, Tröhler, 2013) and earlier tendencies of education reform proposals became massively radicalized. ${ }^{2}$ One of the most prominent spokesmen for educational reform was Harvard President James Bryant Conant who had been quoted in the Bush report Science: The Endless Frontier in 1945 (see above) (Urban, 2010, p. 83f) and another was Hyman George Rickover (1900-1986), known as the "Father of the Nuclear Navy." Shortly after Sputnik, Rickover accused American education and its ideology of "Life Adjustment" and demanded more knowledge rather than cross-curricular competencies: "If the local school continued to teach such pleasant subjects as 'Life Adjustment' and 'How to know when you are really in love,' instead of French and physics, its diploma would be, for all the world to see, inferior" (Time Magazine, 2 December 1957). In this context-for the first time, if I am not mistaken-the idea of national education standards defined by central experts was proposed together with a system of incentives:

In some fashion we must devise a way to introduce uniform standards into American education. It would be best to set up a private agency, a Council of Scholars, financed by our colleges and universities as a joint undertaking-or perhaps by Foundations. This council would set a national standard for the high school diploma, as well as for the scholastic competence of teachers. High schools accepting this standard would receive official accreditation, somewhat on the order of the accreditation given medical schools and hospitals. (Time Magazine, 2 December 1957) ${ }^{3}$

One of the direct consequences of Sputnik was the passing of the National Defense Education Act (NDEA) signed on 2 September 1958, and the relevant debates within and outside of Congress were reconstructed exemplarily by Barbara Barksdale Clowse in her book Brainpower for the Cold War: The Sputnik Crisis and National Defense Education Act of 1958 (Barksdale Clowse, 1981) and-somewhat complementary-by Wayne J. Urban in his book More Than Science and Sputnik. The National Defense Education Act of 1958 (Urban, 2010). Urban's emphasis lies in the fact that NDEA did not only foster the sciences-it certainly did-but also included visions of vocational training, concepts of student loans, development of educational media, strategies of college teacher education, and the 
promotion of statistical services (Urban, 2010, p. 3). And most of all, it included an idea that had been unsuccessfully launched for 20 years, namely the idea of federal aid for the individual state school systems without promoting "federal control" over education (Urban, 2010, pp. 14f., 17). ${ }^{4}$

The idea of federal aid (with or without control) brought a new dimension to the debate, for it transcended the problem of the adaption of the course of studies in the direction of more science. It raised the question about governance. Certainly, on the legal level this question of governance was explicitly not affected:

The defense of this Nation depends upon the mastery of modern techniques developed from complex scientific principles. . . We must increase our efforts to identify and educate more of the talent of our Nation. This requires programs that will give assurance that no student of ability will be denied an opportunity for higher education because of financial need. . . The Congress reaffirms the principle and declares that the States and local communities have and must retain control over and primary responsibility for public education. The national interest requires, however, that the Federal Government give assistance to education for programs which are important to our defense (NDEA, Title I-General Provisions, Findings and Declaration of Policy, Sec. 101., italics added)

However, this would prove to be an illusion, for stakeholders and concerned people wanted to know what effects the federal money that was spent during the following years in education would have. Under President Lyndon Johnson's administration and the aspiration of a Great Society, Congress passed a second National Educational Act in 1965, the Elementary and Secondary Education Act. This act shows precisely the dilemma of educational administration: It aimed at centralized power in a constitutional, legal, and cultural context that was and is highly local. The Act dealt with this dilemma by committing to noninterference with regard to a national curriculum on the one side and by allocating federal money for professional development, instructional materials, and educational programs of desired school subjects on the other. In accordance with the constitutions, the local schools should not be forced to accept curriculum and teaching reforms, but they were to be motivated by incentives.

However, to invest billions of dollars and not be sure about the effects was unsatisfying for the capital providers in their Cold War mission. The constitutional sovereign right of the local authorities prevented the central administration from seeing what kind of results their money effectively had in the schools. It is precisely here that the idea of comprehensive and comparative testing idea in education arose. The instrument was 
the National Assessment of Educational Progress (NAEP) in 1964, which developed tools of comparative testing that were used at a global level in the PISA program 35 years later and that started the Journal of Educational Measurement in 1964. However, this comparative testing initiative was anything but undisputed (American Association of School Administrators; National Education Association of the United States, 1966), for it was understood-rightly—not only as generating data, but as instrument in a new system of school governance in which centralized experts were trying to govern local authorities in education by standards and coercing schools to be accountable to federal standards. When in 1969—after having solved major statistical problems-the first national assessment in education was held, a wave of publications debated the visions and effects of educational accountability and introduced by that a concept-educational accountability — that had been hardly known up to then. ${ }^{5}$

The question is how educational accountability could possibly have become a core concept in educational policy in roughly 10 years after Sputnik. Its introduction included a Second World War and Cold War ideology of problem solving, the faith in experts, some skepticism towards democracy (Martens \& Wolf, 2009, p. 372; Rizvi \& Lingard, 2010, p. 130), and a considerable Trust in Numbers (Porter, 1995) combined with a "'horse race' mentality" (Kamens, 2013, p. 117). This article will reconstruct that first part of this transformation after Sputnik, that is, the rise of the new faith in experts, the rise of educational planners, and statistics. The thesis I want to demonstrate is that this process was possible mainly by a specific rhetoric that was developed as a core means of the change management. The rhetoric was able to level cultural and national differences, and this allowed these new ideals of educational governance to become accepted by the participants and thus to be implemented in their respective places. My example are the years leading up to 1965, when the individual member countries of the Organization for Economic Co-operation and Development (OECD) had to take over the funding of educational programs that had previously been funded by the OECD (and that means it was funded 50\% by the United States). This ideology was transported and disseminated by a specific rhetoric that bypassed politically taboo themes and covered up the clear strategies of governance. This paved the way for the process of standardization and the implementation of not only formal adaptation of the organization of education but also, and in particular, specific ways of educational planning, such as statistics, and with them specific ideologies of how society and its citizens should be shaped. Only a few years later on, educational accountability had become a "normal" part in educational policy with a tendency to be a treated as fetish (Sellar \& Lingard, 2013).

I will demonstrate my thesis in five steps. First, I will shed some light on 
the broader ideological context of the early years of the OECD, that is of its educational commitment (1). Next I will focus on taboo themes (2) and the disguising rhetoric (3). In the next step, I examine in particular one major project of the early OECD, with six Mediterranean countries at the center (4) to check the sustainability of the early efforts in educational planning after a fundamental revision of the OECD activities in $1964(5)$.

\section{THE OEEC, THE IDEOLOGY OF "DEVELOPMENT," AND ITS EDUCATIONAL IMPLICATIONS}

The Organization for Economic Co-operation and Development, OECD, was founded in 1961 as a successor to the Organization for European Economic Co-operation (OEEC) (1948-1961). The OEEC had been an integral part of the Marshall Plan, dedicated to a European economic upswing and-even more so-to the integration of the European nations. All the Western European countries, with the exception of Finland, which was under the strong influence of the Soviet Union and thus in a delicate situation, and including Greece and Turkey, which were seen in danger of turning to Communism, ${ }^{6}$ and from 1950 Yugoslavia, a somewhat reluctant partner of the Eastern bloc, benefited from the American grants and economic cooperation. It is in this context that the notion of the economic miracle was used.

The transition from the OEEC to the OECD in the years 1960-19617 was on one hand due to the inner-European tensions on the question of customs and tariffs in the context of the idea of a European free-trade area, and on the other hand due to Charles de Gaulle's strong opposition to the Anglo-Saxon predominance in Europe. The inevitable transition from the OEEC to the OECD not only included new countries to the organization, such as Canada and the United States, but signified a change that became tangible in the new name. "Europe" had been deleted for obvious reasons, the notion of cooperation remained, but a new notion appeared that proved to be highly significant-namely, the notion of development. The Western countries should not only cooperate but also develop as a whole.

Behind the notion of development-a notion that is not suspicious per se-is almost the whole ideological assumptions of the Western world and foremost of the United States (Gilman, 2003). Like the Soviets for the Eastern bloc, the United States for the Western world headed a homogenous world under its leadership. In order to discredit the competing Soviet agenda, leading intellectuals in the United States labeled the communist ambitions "ideological," whereas the Western self-perception was labeled "the end of ideology" (Bell, 1960). The self-ascription as 
being free of ideology was deduced from the self-assessment that the United States was the most developed country in the world. Looking at its own history, there was little doubt that the United States had solved the major problems of modern societies by far the best. But its self-asserted American exceptionalism did not prevent the rise of the idea that, at the same time, its unique example was also universal and exemplary. In other words, the United States was both unique and a model for others; to create a harmonized globe it had something to offer the world by its very example (Tröhler, 2010).

The self-perception of being both free of ideology and the most developed country allowed a new mapping of the world. Instead of the traditional continents, the world was divided into four categories of development: first, the developed countries, thus the United States and to a lesser degree Western Europe, then the developing countries, Southern and Southeastern Europe and to a lesser degree South America and parts of Asia, undeveloped countries such as most of the African countries, and wrongly developed countries such as the Eastern bloc. Development was no innocent notion but the keyword of a specific ideology that assessed itself as ideology free. This mapping had consequences, for it benchmarked the process of development assistance. Correct development was not necessarily the development of something given, but-if necessarythe implementation of something foreign, which indicates a process of standardization (Chabbott, 2003).

How this ideology was taught can be demonstrated by taking the example of one of the largest projects created by the OEEC in 1958. The project was a direct response to Sputnik. Whereas the United States reacted by founding NASA and by passing the National Education Defense Act (NDEA) in 1958, the OEEC founded the Committee for Scientific and Technical Personnel (CSTP) in the same year, with the British chemist Alexander King-later cofounder of the Club of Rome-as secretary and James Ronald Gass, a British social scientist who did "not know much about education" (Eide, 1990, p. 9), as deputy. This committee was named "responsible for the work of the Organization relating to the expansion and rational utilization of the scientific and technical training necessary for meeting the needs arising from economic growth" (as cited in OECD, 1965, p. 8). Training in relation to economic growth was the key issue of the OEEC with regard to the scientific advance of the Russians, and this task led to perhaps the most important project of the CSTP, the "The Mediterranean Regional Project." The Mediterranean Regional Project was designed to help six European countries, Portugal, Spain, Italy, Yugoslavia, Greece, and Turkey, transform their predominantly agricultural economies to industrial economies by developing educational measures for this transformation. 
The OEEC's CSTP, had no doubt that there were "common aims and responsibilities in the more advanced and in the developing countries" (OEEC/C(60) 207), and the OECD repeated this assessment one year later in 1961 (OECD/C(61)70, p. 5). Accordingly, the CSTP confirmed that problems in the developed and the developing countries were not "different in kind" and that the "real difference was in fact one of degree only" (STP/M(61)1, 2nd session, p. 14): "The difference is one of more and less, and not of otherness, and the goal is to initiate 'a simple process of catching up with the best" (Maddison, 1962, p. 18). At a 4-week training course for ongoing educational planners, an American economist from Ohio State University, Samuel C. Kelley, spoke to the participants. Kelley had made a name for himself with analyses of insurances and income estimations in North Dakota (Kelley, 1954, 1956). Kelley told the future educational planners:

The general nature of the problem, within the Mediterranean Regional Project group, is obviously similar. Each country will require a great increase in the general educational level and in particular, in the proportion of students continuing their education to advanced secondary and higher levels of education. Each will require a redirection of the flow of graduates from educational institutions to the various occupational and industrial sectors. Each will require massive population movements from agriculture to other branches and extensive vertical movement between occupational levels. (Kelley, 1962, p. 29f)

"National differences" are recognized, but only on the terms that they will "necessitate somewhat different emphases on the objectives of the work," so that "some flexibility will be necessary" in order to "make the maximum contribution to national problems" (STP(62)19, p. 14).

\section{BYPASSING TABOO THEMES}

The OECD has often proclaimed that it is a toothless tiger for its lack of executive powers (Leibfried \& Martens, 2008, p. 6; Rizvi \& Lingard, 2006, p. 247). This might be one of the reasons why the predominant rhetoric used by the OECD is, to say the least, cautious. In contrast to the very clear ideas of development in the context of the Cold War, the rhetoric used by the OECD is reserved and neglects accordingly important facts and events and remains rather monosyllabic.

Perhaps the most striking neglect is that the OECD—although being a Cold War institution-did not mention notions of war, army, the Iron Curtain, armed forces, weapons, etc., at all, although the curricula reform 
was heading towards more sciences and technology. This expresses the overall ideology of the West, to label the Soviet aspirations as "ideological," whereas the Western ambitions were "free of ideology" (Gilman, 2003, p. 58, Tröhler, 2010) because they were technological. The prime example is the above mentioned bestseller of the time, Daniel Bell's The End of Ideology (Bell, 1960) in which Bell acknowledged the eclipse of class ideology in Western countries and the emergence of a welfare system in which people would solve their problems pragmatically with the help of new scientific and technological tools. Technology was seen as beyond ideology, numbers too, and so would the systems of accountability: neutral, objective, helping policy makers in their task to develop their societies. Accordingly, while declaring the outline of the general program of the CSTP in the newly founded OECD, the Council declared: "We are deeply convinced that science and technology, and the advanced education on which they must be based, are the pillars on which future social and economic progress must be built" (OECD/C(61)70, p. 1) -apparently only for economic development and not for the arms race that was taking place in those days. The only exception in the OECD papers or publications is the citation of Carl von Clausewitz' book, On War (first published as Vom Kriege in 1832), with discussion of Clausewitz' definition of strategy in educational planning (Lyons, 1962, p. 57). ${ }^{8}$

Another term that is missing, and this may be more surprising, is the notion of democracy. Although the development of the Western societies was allegedly the main aim of the OECD, the mutual connection between education and democracy had been emphasized over and over since the French Revolution in 1789. In all the internal papers and publications between 1960 and 1964 that I have been reading, democracy is named once. In this one instance, in the training course for ongoing educational planners mentioned earlier, the expert tried to convince his audience that in a "political democracy" it is important that the citizens know about the influences of technology, economy, and the social and political spheres on their own lives (Parnes, 1962, p. 74) ${ }^{9}$ Alternative notions to democracy do not exist, again with one exception-namely, the notion of a "free society" (Kelley, 1962, p. 33).

In accordance with this neglect is the almost total absence of mention of important figures in global politics. President John F. Kennedy is the only political leader who is mentioned, and again only one time, and again on the occasion of the training course. The British economist John Ernest Vaizey, who published The Cost of Social Services in 1954 (Vaizey, 1954), on The Costs of Education in 1958 (Vaizey, 1958), and The Economics of Education in 1962 (Vaizey, 1962a), mentioned John F. Kennedy in the following context. After having complained about the "prostitution of the argument for 
social equality in education by a glorification of "working class culture,"” and after the blaming the negative effects of "a limited, academic classical curriculum" at school, Vaizey mentions the new president of the United States as follows:

A truly cultivated man must surely be well-read, musical, a good linguist, a good conversationalist, have good taste in food, women and theatre, and be reasonably fit. A man like Mr. Kennedy, for example. But that just shows how hard it is to be civilized unless you are rich. And to be rich by your own efforts means you have to earn your living profitably. Frankly, that is what I think the cultural debate reduces itself to. (Vaizey, 1962b, p. 42)

In the early OECD papers and publications, there are few passages that reveal the unspoken cultural ideology of the OECD as clearly as this one does. Here, Kennedy serves as a model for the advantages of wealth, whereas public debates about the problems of equity and of "working class culture" are ridiculed. As is usual in OECD arguments, the "enemy" is not identified, but in this context it is clear that Vaizey is attacking recent British publications about the working class in England, basically the working class sympathizing with their own culture and being skeptical about the political order of capitalism-Brian Jackson and Dennis Marsden had just published their bestselling Education and the Working Class (Jackson \& Marsden, 1962), and a year later Edward Palmer Thompson would publish his seemingly timeless sociological classic, The Making of the English Working Class (Thompson, 1963). The message is clear: In the context of the Cold War the participation of skeptics about capitalism is undesired and thus the persuasiveness of the ideals of democracy limited. ${ }^{10}$

Other "hot" topics that undoubtedly were of immense importance to the OECD and its bearers remained unspoken, too, so for instance the erection of the Berlin Wall more than 50 years ago in 1961, or the first human spaceflight on April 12th, 1961, by Soviet cosmonaut Yuri Gagarin, or the failed invasion of the Bay of Pigs in Cuba a couple of days later. Not even the assassination of John F. Kennedy, according to John Vaizey, the model of a happy man, on November 22nd, 1963, found any echo in the context of the OECD. Certain topics that were obviously in the core of the ambitions of the OECD remained simply untouched. This specific rhetorical character was supplemented by another, namely, the rhetoric that covered up, relativized, hid the sources of parts of their arguments and remained unclear about its own aims. 


\section{THE DISGUISING RHETORIC}

Reading the OECD papers and publications suggest that the OECD relativized its political determinations by veiling its strategy. The language used in the OECD papers is neither academic nor an official government language; it suggests merely assistance and support, but it aims at implementation of an unspoken Cold War ideology. For instance, STP wrote that it aimed at "helping the development of national policy towards the effective revision of the teaching of scientific subjects, within the framework of a more general policy designed to increase the quality and quantity of scientific and technical personnel" (STP(61)15, p. 1, italics added) and that it wanted to "stimulate interest in Member countries by helping the development of national policy towards the effective revision of the teaching of scientific subjects" (OECD/STP(61)3, p. 1, italics added)STP never said what it was convinced of: That it had indeed the real recipes for educational reform and that the member countries should adapt them. Nay, STP reported solely that certain problems were "felt by most Member countries" (STP(62) 19, p. 8, italics added) and that the member countries shared "strong concern" about developments and that the linking together of long-term economics with the development of the educational system was becoming "rapidly recognized in several Member countries, as for example in the countries participating in the Mediterranean Regional Project." The experiences of this Mediterranean Regional Project “indicate that the effects on educational policy in the countries may become substantial" (STP(62)19, p. 10, italics added) and that there was "reason to interpret the response to the idea of establishing pilot planning teams as an almost general interest in Member countries" and that the close contacts between the individual member countries was "likely to have a major impact not only on methods of approach to educational planning, but on actual policy decisions taken by national authorities" (STP(62)19, p. 10f, italics added).

The establishment of national planning teams co-operating with the O.E.C.D would at the same time provide the Organization with channels to national sources of information which, if properly used, should add substantially to its capacity to undertake comparative international studies to the benefit of all Member countries. (STP $(62) 19$, p. 11, italics added)

However, if the OECD, or the secretariat of the "Office of Scientific and Technical Personnel" (STP) program, was to collect this data in order to "add substantially" to the member countries "it seems to be essential to reorient the program at work of the Secretariat" (STP(62) 19, p. 16, italics added), which meant assigning more autonomy. This indeed happened 
during the discussions in 1962, and self-confidently the language changes a little bit, for in 1963 the OECD wanted "to ensure that the right share of increased national effort in education is allocated to the sectors of scientific and technical education which ... are one of the keys to national economic development" (STP(63)14, p. 25), for it was becoming "reasonably clear," as it had been reported in 1964, that there is the need "in ensuring that the results of the MRP are adequately reflected in policy at the Ministerial level" (STP(64)17, p. 3, italics added).

Obviously, the rhetoric hardly formulates concrete research questions, and the state of research is hardly ever discussed; citations of research are an exception and mostly restricted to the experts of the OECD. How the relativizing rhetoric is linked with allusion to the dominant economic theory of the OECD becomes clear in the following paragraph:

Several indications point in the direction that investments in what is often called "human capital" —out of which investments in formal education constitute a major part-might be the main source of the unexpected part of the actual economic growth in most countries. It seems that under certain circumstances, the role played by investments in education may even be more important than that of investments in physical capital. (STP(62) 19, p. 7, italics added)

The OECD based its strategies on "the growing realization" that education and training were important factors in economic growth and that "in fact, recent economic research has shown" that besides labor and physical resources there was a "third factor' of production, in which education is presumed to be an important element" (OECD, 1965, p. 5, italics added). The notion of the "third factor" goes back to John Vaizey, the OECD expert who admired John F. Kennedy for his wealth and who had invented the notion of the "third factor" in his affirmative discussion of the human capital theory (Vaizey, 1961, p. 97); and it is significant that this original source, Vaizey's article, is not identified in the official OECD publications nor in an internal paper (STP(62)5, 2nd revision, p. $5)$. Whereas one might interpret this practice as understatement, it can equally be interpreted as a more or less conscious strategy by the OECD to almost always refrain from identifying its authors clearly. Statements are to be made, not discussed.

In this context a last rhetorical factor deserves to be named-namely, the uncertainty about the aim of educational reform. Clearly, political aims are not mentioned-democracy is not envisaged as an aim. Very often, the aim is double-namely, "economic and social development." In the OECD papers, statements such as the following are repeated like a mantra: 
The O.E.C.D. policy approach ... may be simply expressed as the recognition that education must be looked upon as an investment which is intimately related to the future of economic and social progress of the individual nations, and of the O.E.C.D. area as a whole. (STP (63)5, p. 1)

Here the notion of progress is often replaced by development. The social dimension of the OECD mission is constantly confirmed-but in a strikingly defensive way. It is held that the "educational strategy should be planned within a wider economic and social framework" and that it "may be mentioned that . . social claims on educational resources have not been neglected" in their concrete activities (STP(64)19, p. 5). The defensive character of the emphasis on the social dimension is not by chance, and early critics had complained about the deficit of social questions in the context of the OECD agenda. And it is clear why, namely because social development was seen as a result of a more important development, the economical: "Some persons have such a profound feeling that the 'true' purpose of education is to contribute to an individual's personal development that they regard as almost immoral an approach to educational planning that is essentially economic in its orientation and which seems to use society's needs for a 'human capital' as basic criterion" (Parnes, 1962, p. 73f). In 1969 this preference was confirmed (but retrospectively somewhat relativized) ${ }^{11}$ by James Ronald Gass, who meanwhile had become Director of the Centre for Educational Research and Innovation (CERI) in the OECD: "In the O.E.C.D. countries in the last ten years educational planning has developed rather on the model of economic planning: we have educational planners with the technical function in Ministries of Education for preparing educational plans which are to be 'implemented'" (Gass, 1969, p. 3).

The integration of "educational and economic policy" had been the ultimate goal of the early OECD (STP(62)5, (2nd Revision), p. 5). The promised social development and benefit was understood (mainly) as the/a result of economic development based on innovation in education (STP(62)1, pp. 3f) - that is, on the implementation of reform programs heading for the general expansion of the education systems, a focus on more sciences and mathematics in the curriculum, and the implementation of efficient teaching methods, such as the teaching machines and school radio and school television. The development of the pertinent skills of policy implementation-called "educational planning through experts" - was in the center of one of the most ambitious programs of the OEEC and the early OECD, the "Mediterranean Regional Project." 


\section{THE TRAINING OF EDUCATIONAL MANAGERS}

The concrete educational programs within the "Committee for Scientific and Technical Personnel" (CSTP) were situated between the global Cold War ideology of development and the moderating rhetoric with regard to the aims, strategies, and national sovereignties of the countries to be developed. This becomes particularly clear in the "Mediterranean Regional Project" (abbreviated MRP), starting in 1960 with an agreement between what was then the OEEC and six Mediterranean countries-Portugal, Spain, Italy, Yugoslavia, Greece, and Turkey. ${ }^{12}$ It established national teams in each country, aimed at analyzing the way their economies could be developed by means of educational innovation foremost in science and technology. The individual teams were to be composed of a director and "economists, statisticians and educationalists" who were to be "appointed by and be reporting to the Government concerned" (OECD, 1965, p. 9). Therefore, the national sovereignties were guaranteed, and the OEEC was willing to take over $50 \%$ of the individual countries' total costs.

In the self-perception of the OEEC and then the OECD, this cost transfer of $50 \%$ of the national costs was only one of the services to the whole project. The provision of international experts was another, and the organization of the whole project-regular meetings, mostly in Paris, conferences, etc.-was a third. And there was a fourth service that was offered and willingly accepted by the member countries-namely, the training of "specialists in human resource development" (OECD, 1965, p. 9). This training program was twofold; on the one hand, it included a one-year fellowship for "young economists" in the frame of the national teams (STP/ GC(61)25, p. 4), and on the other hand, it provided an annual 4-week crash course at selected locations; in 1962 the course took place in Italy, in 1963 in Greece, and in 1964 in Germany. The participants in these annual 4-week crash courses were individuals not only from the Mediterranean countries but also from the Western European countries, which themselves were organized in a parallel program to the Mediterranean Regional Project (or MRP), a program called "Investment Planning in Educational Development" (IPE).

The need for trained educational planners was derived from the overall plan of the MRP, and this plan was quite clear and in principle simple. It was a four-step plan, including analysis of the present conditions, forecasting of the needs of the future, ideas for programs for development from the present to the future needs, and the financing of these programs (STP(63)8, p. 8). Every country participating in the MRP had to deliver a country report on the four aspects, present analysis, future estimation, implementation programs, and finance models. All four of these aspects 
had to programmatically developed by the OECD, and it is no coincidence that the pioneer role of the whole endeavor was emphasized over and over (STP(63)8, pp. 7, 12; STP(64)17, p. 9; STP(64)19, p. 6; STP/M(64)3, p. 20 ). The analysis of the present educational system was basically a statistical affair, the estimation of future needs was an issue of curriculum reform and teaching innovation in the context of economic forecasts under the umbrella term "manpower requirement" (OECD, 1962, pp. 67-165) both were organized in special working groups of the OECD. The question of implementation was a matter of educational planning of human resources, for which the fellowship program I mentioned earlier was set up for the Mediterranean countries and the parallel program "Educational Investment Planning" for the more developed countries. And the discussion of the finance models created the genre "economics of education," for which the OECD created its own working group, too.

Although the first step, statistical examination of the individual countries, did not cause any specific problems per se, the question of curriculum reform and efficiency and finance was developed in the realm of the OECD with experts from the developed countries. In the logic of the OECD strategists, the real crux was the training and subsequent implementation of strategists in either the ministries or in pertinent organizations in the individual countries, for the OECD had no power to interfere with the national sovereignties. The training programs were accordingly twofold: For one, they aimed to acquaint the participants with the general theories and strategies of educational planning, and for another, they aimed at the same time at the participants' conformance with the ideology behind the theories.

The annual fellowship program for "Junior Experts" proved to be very successful, for over 300 young men applied for the 1963 program, of which 44 were interviewed, and 16 accepted $(\operatorname{STP}(63) 16$, p. 1). Together with additional interested people of all the OECD countries, these fellows came together in the annual 4-week courses mentioned earlier for an impressive four-page syllabus of the program (STP(62)2, Corrigendum 2, pp. 3-6). "Growth Problems in Underdeveloped Countries," "Roles of Education in Developing Society," and "Economic and Educational Planning" were the first 3 of 17 lectures in the 4 weeks. The list of speakers reveals a dominance of Anglo-Saxons. The person responsible for the 1962 annual meeting in Italy was Herbert Saul Parnes, a political scientist and economist at Ohio State University; four papers were presented by Americans, seven by British scholars, two by French colleagues; the other papers were presented by authors from different countries.

One of the most important tasks of these conferences was to convince the young generation of educational planning experts of the importance 
of their mission. It was up to a second professor of economics at Ohio State University, Samuel C. Kelley, to take up this task. One of the major problems, Kelley told conference participants, is that people in traditional agricultural economies, such as the Mediterranean countries, did not have "appropriate' behavior" for the envisaged development, so that it was one task to change "human attitudes and motivation which result in specific acts of commitment to a work role and a way of life" (Kelley, 1962, p. 27). With this transformation towards economic progress Kelley did not promise a rose garden: "There are no means to economic progress that are not, in some degree, coercive" (p. 28). It would be "the nature of industrialization" to disrupt traditional arrangements, but, as Kelley reassured, "the benefits on an industrial order will exceed the costs" (p. 28) of this process. Whereas the developed countries had an easier development due to their cultural dispositions, the countries developing now would have a harder task: Here, the "process of change will require a much greater concern with the means of commitment than was evident in the evolution of the [already] developed countries" (p. 32). It is exactly here that educational planning plays a crucial role: "Educational planning should recognize the implications of education in this respect and the patterns of education should develop in ways that are consistent with these needs" (p. 34).

Strategically, the main target groups were not the students or teachers but the ministries of economics and education in the different OECD countries. During the training course the British administrator Raymond F. Lyons-who up to then had been a rather dark horse in the scientific community-taught the ongoing educational planners how to report facts and programs to the national ministers in his lecture, "Formulating Recommendations on Educational Needs" (Lyons, 1962). To write a "useful guide for policy makers," Lyons said, depends on five factors, and these factors constituted nothing less than the recipe of an international bureaucratic language in educational policy. First, Lyons advised, the governments need to be basically committed to the work undertaken by the strategists. Second, the report should always begin with "a short introductory chapter summing up clearly and concisely the findings of the investigation and the conclusions drawn from them"-relativizing or limiting comments on these findings and conclusions are to be omitted (Lyons, 1962, p. 245). Third, the report should be "balanced"-balanced meaning offering a consideration of both educational and economic claims (pp. 245f). Fourth, Lyons warned of "too much indulgence in academic exercise" (p. 246), for it has "no immediate and practical relevance and may do more harm than good" (pp. 246ff.). And fifth, Lyons reminded the audience to be careful with alternatives to the proposed programmatic steps: 
It is unwise to introduce into a report the degree of fluidity which is inherent in too many alternatives. Moreover, ministers and politicians are always tempted to accept the alternative which carries the lowest cost. Lastly, alternatives may suggest lack of confidence on the part of the authors and thus throw doubt on the solidity of the report itself. (Lyons, 1962, p. 247)

Texts or reports by strategists or educational planners are not committed to academic considerations and possibilities but to clear and unchallenged agendas.

\section{STANDARDIZATION AS OUTCOME AND AS STARTING POINT FOR ACCOUNTABILITY}

As did some other OECD countries, the six nations involved in the MRP delivered their national reports in the years 1963 and 1964, and they were discussed at length in the context of the CSTP and finally published in an OECD series titled, "The Mediterranean Regional Project" (in Turkey in 1964, in Spain, Greece, Italy, and Yugoslavia in 1965, and in Portugal in 1966); a short summarizing overview was published in 1965 (OECD, 1965).

The discussions in the realm of the OECD showed an ambivalent picture. On the one hand, the reports delivered data that had not existed before, but the data from the different countries proved to be not really comparable and so were of little use. In a lecture at the third training course, held in Germany in July 1964, Frederick H. Harbison, Professor of Economics at Princeton University, explained to the strategists-in-training that exactly because the different countries were "at different stages of modernization," comparative analysis of comparable data was essential: "From the standpoint of practical politics, the consideration that really influences policy-makers and even the people as well, is comparison with other countries. In this respect, nations resemble individuals-they want to keep up with the Joneses. And this is true of all countries, including the United States" (Harbison, 1966, p. 54).

As a matter of fact, the conclusions were sobering. Michel Debeauvais, a French administrative scientist who took an international comparative approach and former collaborator with the ministry of foreign affairs (1947-1959), politely labeled the data from the MRP "of great interest" but assessed the data succinctly as "not suitable for international comparison for lack of common methodology" (Debeauvais, 1962, p. 85). Debeauvais traced the problems identified partly back to the ideological differences between educationalists and economists, for educators were 
identified as "used to talking in terms of teaching and social objectives but are chary of the terminology and concerns of economists and manpower experts" (p. 86). However, the major problem was an appropriate methodology: Comparative statistics had to be developed, for only comparative data were considered to be helpful to the mission of the OECD. "The qualitative aspects of educational programs are of course most important, but are specific to each country and do not lend themselves to generalization. Here, again, a number of parameters should be considered" (p. 95).

Accordingly, the need for improved statistics was often repeated. To the further development of this concern the first visible fruits of the OECD activities were helpful. At the Fourth Conference of the European Ministers of Education in 1964, the Committee for Scientific and Technical Personnel (CSTP) was assigned to be in charge of planning and investment in education (STP/M(64)2, p. 13). This assignment was balm for the CSTP actors, and the CSTP secretariat immediately published a separate note titled, "The Need for Improved Statistics" (STP(64)24). To fulfill the assignment, the note says, problems should be solved in order to assure that the "statistics of the Member countries will be comparable" (STP(64)24, p. 1), and this task was called the "most urgent task since no real progress can be made without adequate statistical basis" (p. 2). The major mission of the CSTP-longer term economic growth in relation to education and scientific research-was even assessed as being at risk without "comparable data" (p. 3), so that the "Member countries of the OECD are in a position to make a major and trend-setting advance in the field of comparative statistics for educational investment planning" (p. 4) in order to allow "national authorities to establish in quantitative terms realistic targets for the whole system of education and training" (p. 5). The definition of comparable indicators should allow a "continuous statistical series showing, on a comparable basis, the educational effort and levels on educational attainment in various countries" (p. 5).

However, not all the OECD countries should profit from these coming developments, for at the same meeting in which the assignment by the European Ministers of Education was discussed, the confidential revision of the STP by the Deputy General-Secretary of the OECD, Michael Harris, was announced (STP(64)2, p. 4). In his "Review of the Operational Activities of the Organization" (CES(64)22) Harris favored for the future those quantitative projects that allowed for comparative data, and he proposed to turn down all experiments that were not paid for by the member countries and all qualitatively oriented projects such as curriculum reform or the development of teaching aids.

It is in this context that the idea of central steering by quantified 
standards and the implementations of partially autonomous units was born. This is an idea that was first formulated at the level of OECD and individual countries, and then on the level of countries and individual schools. It is an idea that explicitly requires "some reduction of the powers wielded by local authorities over educational matters in favor of larger regional authorities or of the central government"-or the OECD (STP(64) 19, p. 23).

According to Harris, curriculum reform had been completed to considerable success; its results were published in 1966 in a report titled, "Curriculum Improvement and Educational Development," with a foreword by Harris (OECD, Stoke, Löwbeer, \& Capelle, 1966). In particular, the financial assistance to all countries was stopped, which triggered a heated discussion in the Committee for Scientific and Technical Personnel (CSTP) (STP/M(64)3, pp. 4-24). Indeed, this suspension of fundswhich was not withdrawn despite the vehement opposition-turned out to be a real elk test for the pertinent activities of the OECD. Launched in the wake of Sputnik with a tremendous amount of money from the United States during 6 years, the crucial question was: What effects were to be found? The losers were obviously the countries of the Mediterranean Regional Project who had profited from the allocated money-a sarcastic reading would be that they were now regarded as developed and thus without additional need of foreign money. But who was the winner? It was the OECD. Most of the Western European countries-having participated in the program parallel to the MRP, the Investment Planning in Educational Development (IPE), were willing to continue and to bear the costs themselves. Obviously, they had adopted the planning ideology under the keyword of development and had therefore set up administrative organizations in their respective countries. Of all the countries, Germany had been the first, by establishing the Institut für Bildungsforschung (Institute for Educational Research) in the realm of the Max-Planck-Society in 1963-1964. ${ }^{13}$ The United Kingdom founded the Schools Council for the Curriculum and Examinations in 1964, Greece established a National Pedagogical Institute in 1964, and the Netherlands founded a Foundation for Educational Research in 1965.

The institutionalizing of the OECD offshoots in the different developed countries enabled the development ideology to become a standardized model of educational policy. Without these institutions the participation of the OECD member countries in the CERI-the Center for Educational Research and Innovation founded by the OECD in 1968-would not have been conceivable. They had clear ideas about educational planning, about development, and about research, and they participated in the OECD programs Education at a Glance and PISA, in the beginning somewhat 
reluctantly but in the end supportingly (Henry, Lingard, Rizvi, \& Taylor, 2001, p. 87; Weymann \& Martens, 2005, p. 79). They had forgiven the OECD for the fact that they had not really been involved in the planning and execution of the different activities or in the selection of the external experts and consultants, as they had complained strongly in 1963, and had then been told by the secretary, Alexander King, that they were not familiar enough with the issues at stake to evaluate the Committee's work (STP/M(63)2, pp. 9f). The Cold War, respectively, the OECD, had given them an important place in the reformed educational bureaucracies of their respective countries, and conversely, they implemented the new logic of educational planning with reports and popular publications published in their countries and not with OECD publications from Paris. For instance, the Swede Hans Löwbeer, who became president of the Swedish National Board of Education in 1964, published the booklet The Educative Society (Löwbeer, 1965) in 1965, and the German Friedrich Edding, who became one of the directors of the newly founded MaxPlanck-Institut für Bildungsforschung in 1964, published the booklet, Bildung und Politik [Education and Politics] (Edding, 1965) in 1965. They and their successors continued their work, expanding in their countries the educational bureaucracies the same way as the educational systems, fulfilling the ambitions of comparative statistics by standardizing the educational systems, such as through the Bologna program, and standardizing even the school contents, in order to facilitate quantitative comparative research: They contributed heavily to the successful establishment of an international bureaucracy of education, or in the language of the OECD, of the establishment of an international educational "machinery" (STP(64) 19, p. 23 et passim). At the end of the implementation of this machinery-around 1970 in the United States, some 20 years later in Europe-were the schools, accountable for their performances that they had to achieve in direction of predefined standards.

However, being confirmed in the important roles they played internationally and nationally and committed to their mission between politics and scientific research, over the course of time these experts seem to have simply ignored the fact that the Cold War came to an end some while ago and that the acknowledgement of cultural diversity and difference is now at stake. If the educational bureaucracy and its logic of expertise, standards, and accountability does not recognize this fact, it might be the duty of the educational sciences to remind them, if you will in reports: With a short summary in the beginning including the findings, being balanced, avoiding too much academic indulgence, and omitting alternatives. It has proven to be a successful style. 


\section{NOTES}

1. Vannevar Bush (1890-1974) had been an engineer at MIT and developed a machine that became known as Rockefeller Differential Analyzer, a modern calculating machine and forerunner of the computer. From 1937 Bush developed the Navy Comparator that was to be used to find compliances in coded messages. In 1938 Bush became President of the Carnegie Institution for Science, in 1940 Science Advisor to President Roosevelt and head of the National Defense Research Committee (NDRC), and in 1941 Director of the Office of Scientific Research and Development (OSRD). The OSRD coordinated during the Second World War the military research programs, among others the Manhattan Project in which the atomic bomb was developed, and he was committed to the development of the radar and sonar, systems designed to location objects underwater via emitted sound impulses. Both radar and sonar helped the U.S. Navy successfully fight the German submarines during the war. In 1943 Bush was awarded the des Institute of Electrical and Electronics Engineers (IEEE) Medal for the application of mathematics in technology and for his service to the nation in his job as heads of the program in weapons development. In April 1944 Vannevar Bush was on the front cover of Time Magazine and labeled as General of Physics.

2. John Rudolph in his brilliant Scientists in the Classroom (Rudolph, 2002) has demonstrated how science education underwent some reforms during the early 1950 s as a consequence of raising critiques towards American education in the context of the Second Read Scare of the McCarthy era (Rudolph, 2002, pp. 17ff.). One of the major exponents was the American historian Arthur Bestor (19081994) who in his article "Aimlessness in Education" accused the American education of subverting the Americans: "The subversion of American intellectual life is possible because the first twelve years of formal schooling . . . have fallen under the policy-making control of educators who have no real place in-who do not respect, und who are not respected by-the world of science, of scholarship, and of the learned professions. The fifth column that engineered this betrayal was composed of professors of education" (Bestor, 1952, p. 114) - a year later followed his bestseller Educational Wastelands (Bestor, 1953), repeating the same accusations.

3. The Time Magazine interview with Hyman George Rickover about educational questions was not just a flash in the pan; in 1959 Rickover published the book Education and Freedom (Rickover, 1959), in which education is defined in a military language as "first line of defense" (p. 15). In 1961 the book was republished with a foreword by the former military journalist Edward Roscoe Murrow and with a preface by Charles Van Doren (who had become famous in the quiz show scandal Twenty-One). Three years later Rickover published Swiss Schools and Ours: Why Theirs are Better (1962), a year later American Education, a National Failure: The Problem of Our Schools and What We Can Learn from England (1963), and at the end of the 1960s Liberty, Science, and Law (1969).

4. One of the authors of the NDEA, Lister Hill, a liberal democrat from Alabama, had as early as in 1941 raised the issue of federal aid to education and in 1947 he repeated his claim with regard statistical data according to which the United States 
spent only $1.5 \%$ of its income on education, whereas "other nations such as Britain and Russia spent 3 percent and 7.5 percent respectively" (Urban, 2010, p. 17).

5. Just to list some of the 1971 publications on educational accountability: Roberson (1971), Jordan (1971), Lieberman (1971), Cornell (1971), Fischer (1971), Cupp (1971), and Berg (1971).

6. Actually, Greece and Turkey had been privileged to receive financial aid before the foundation of the OEEC. In his Special Message to the Congress on Greece and Turkey on March 12, 1947, President Harry Truman asked Congress for immediate financial aid for both Turkey and Greece, which were being threatened by communist rebels: "The seeds of totalitarian regimes are nurtured by misery and want. They spread and grow in the evil soil of poverty and strife. They reach their full growth when the hope of a people for a better life has died. We must keep that hope alive. The free peoples of the world look to us for support in maintaining their freedoms. If we falter in our leadership, we may endanger the peace of the world-and we shall surely endanger the welfare of this Nation." Truman was successful and was able to convince the congress: Both countries got obtained several hundred million dollars by the U.S. government in 1947 (Truman, 1947).

7. The convention was signed on December 14, 1960, in Paris. For an account on the transition, see Griffiths (1997).

8. Clausewitz had been a propagator of deterrence through massive armament, an idea that was popular in the Cold War.

9. There is another exception, the welcoming address of the Swedish Minister of Education and Ecclesiastical Affairs Ragnar Edenman on the occasion of the OEEC conference "Ability and Educational Opportunity in a Modern Economy" (Edenman, 1961, p. 2). Edenman was not a part of the OECD, but Sweden was, of course.

10. In addition to the British suspicion towards working class-friendly sociology, the American reformers were reserved towards democracy, because they had been bothered constantly by the democratically elected local school boards in the communities, which exactly at this time were opposing national testing as federal assessment of the schools (Tröhler, 2011).

11. In 1969 the euphoria about the unlimited economic progress and development had been dampened. In 1968, Alexander King had become the cofounder of the Club of Rome, raising considerable public attention in 1972 with its report The Limits to Growth (Meadows, Meadows, Randers, \& Behrens, 1972).

12. If we look today at the long-term effect of this program, designed to develop the economies and societies of these countries in several decades, we can't be very convinced by the efficiency of it.

13. One year later, in 1964, the Hamburger Abkommen (Hamburg Treaty) was passed in order to harmonize the terminology in schooling, the school year, the start and duration of compulsory schooling, vacation, acknowledgements of certificates, etc. The following year, in 1965, the German Bildungsrat (Education Council) was founded in order to cope more efficiently with the different school systems in the different Bundesländer. In 1970 the Bund-Länder-Kommission took over these issues, and the Bildungsrat dissolved in 1975. 


\section{REFERENCES}

American Association of School Administrators; National Education Association of the United States. (Eds.). (1966). National educational assessment: Pro and con. Washington, DC: American Association of School Administrators and Organization Relations Division and Publications Division of the National Education Association.

Barksdale Clowse, B. (1981). Brainpower for the cold war: the Sputnik crisis and National Defense Education Act of 1958. Westport, CT: Greenwood Press.

Bell, D. (1960). The end of ideology: On the exhaustion of political ideas in the fifties. Glencoe, IL: Free Press.

Berg. L. (1971). A study of educational accountability for evaluation. Aberdeen, SD: Northern State College

Bestor, A. E. (1952). Aimlessness in education. Scientific Monthly, 75, 109-116

Bestor, A. E. (1953). Educational wastelands. Urbana, IL: University of Illinois Press.

Bush, V. (1945). Science the endless frontier: A report to the President by Vannevar Bush, Director of the Office of Scientific Research and Development, July 1945. Washington, DC: US Government Printing Office. Retrieved from http://www.nsf.gov/od/lpa/nsf50/vbush1945.htm

Chabbott, C. (2003). Construction education for development. International organization and education for all. New York: Routledge.

Cornell, T. D. (1971). A format for monitoring the teaching-learning process: Educational accountability. Tucson, AZ: Educational Innovators Press.

Cupp, D. E. (1971). An evaluation technique for determining educational accountability (Unpublished master's thesis). Eastern Washington State College, Cheney, WA.

Debeauvais, M. (1962). Methods of forecasting long-term manpower needs. In OECD \& H. S. Parnes (Eds.), The Mediterranean Regional Project. Planning education for economic and social development (pp. 85-96). Paris: OECD Publishing.

Edding, F. (1965). Bildung und Politik. Pfullingen, Germany: Günther Neske

Edenman, R. (1961). Address given by Mr. Ragnar Edenman, Minister of Education and Ecclesiastical Affairs, Sweden, and the opening session of the O.E.E.C. conference on ability and educational opportunity in a modern society. OECD Archives, Paris, France: STP(61)2, Annex I, pp. 2-5.

Eide, K. (1990). 30 years of educational collaboration in the OECD. Oslo: Norway: Royal Ministry of Education and Research.

Evans, R. W. (2011). The hope for American school reform: the Cold War pursuit of inquiry learning in social studies. New York, NY: Palgrave Macmillan

Fischer, J. H. (Ed.). (1971). Conferences on educational accountability [proceedings]. Princeton, NJ: Educational Testing Service.

Fousek, J. (2000). To lead the free world: American nationalism and the cultural roots of the Cold War. Chapel Hill, NC: University of North Carolina Press

Gass, J. R. (1969). Planning the educational revolution. Paris: Unesco-International Institute for Educational Planning

Gilman, N. (2003). Mandarins of the future. Modernization theory in Cold War America. Baltimore, MD: The Johns Hopkins University Press

Griffiths, R. T. (1997). 'An act of creative leadership': The end of the OEEC and the birth of the OECD. In OECD \& R. T. Griffiths (Eds.), Explorations in OEEC history (pp. 235-256). Paris: OECD Publishing.

Harbison, F. H. (1966). Strategies for human resources development (1). In OECD (Ed.), Human resources development. Training course. Lectures and methodological essays on educational planning. Bergneustadt, 6-24 July 1964 (pp. 39-54). Paris: OECD Publishing.

Hartman, A. (2008). Education and the cold war: the battle for the American school. New York, NY: Palgrave Macmillan. 
Henry, M., Lingard, B., Rizvi, F., \& Taylor, S. (2001). The OECD, globalization and education policy. Amsterdam, London: Pergamon.

Jackson, B., \& Marsden, D. (1962). Education and the working class: Some general themes raised by a study of 88 working-class children in a northern industrial city, 1946-1960. London: Routledge \& Kegan Paul.

Jordan, B. (1971). Educational accountability: A crucial question. Junior College Journal, 41(March), 23-25.

Kamens, D. H. (2013). Globalization and the emergence of an audit culture: PISA and the search for "best practices" and magic bullets. In H.-D. Meyer \& A. Benavot (Eds.), PISA, power and policy. The emergence of global educational governance (pp. 117-139). Oxford: Symposium Books.

Kelley, S. C. (1954). The population, labor force, and income of North Dakota, 1900-1975. Grand Forks, ND: Bureau of Economic and Business Research, University of North Dakota.

Kelley, S. C. (1956). The North Dakota old age and survivors insurance system; an analysis for the Legislative Research Committee. Grand Forks, ND: Bureau of Economic and Business Research, University of North Dakota.

Kelley, S. C. (1962). The role of incentives in human resource planning. In OECD \& H. S. Parnes (Eds.), The Mediterranean Regional Project. Planning education for economic and social development (pp. 27-37). Paris: OECD Publishing.

Leibfried, S., \& Martens, K. (2008). PISA - Internationalisierung von Bildungspolitik. Oder: Wie kommt die Landespolitik zur OECD. Retrieved from http://www.sfb597.uni-bremen.de/ download/de/ueber/presse/pr_stimmen_0803_leviathan.pdf

Leslie, S. W. (1993). The cold war and American science: the military-industrial-academic complex at MIT and Stanford. New York, NY: Columbia University Press.

Lieberman, M. (1971). Educational accountability. Kanawha Valley Graduate Center, WV: West Virginia University.

Löwbeer, H. (1965). The educative society. Stockholm, Sweden: The Swedish Institute for Cultural Relation with Foreign Countries

Lyons, R. F. (1962). Formulating recommendations on educational needs. In OECD \& H. S. Parnes (Eds.), The Mediterranean Regional Project. Planning education for economic and social development (pp. 245-249). Paris: OECD Publishing.

Maddison, A. (1962). Growth problems in underdeveloped countries. In OECD \& H. S. Parnes (Eds.), The Mediterranean Regional Project. Planning education for economic and social development (pp. 17-25). Paris: OECD Publishing.

Martens, K., \& Wolf, K. D. (2009). PISA als Trojanisches Pferd: DieInternationalisierung der Bildungspolitik in der OECD. In S. Botzem, J. Hofmann, S. Quack, et al. (Eds.), Governance als Prozess. Koordinationsformen im Wandel. (pp. 357-376). Baden-Baden: Nomos.

Meadows, D. H., Meadows, D. L., Randers, J., \& Behrens, W. W. (1972). The limits to growth. New York: Signet Books

OECD (ca. 1960-1965). Unpublished documents. OECD Archives, Paris, France.

OECD. (1962). Planning education for economic and social development. Paris: OECD Publishing.

OECD. (1965). The Mediterranean Regional Project. An experiment in planning by six countries. Paris: OECD Publishing.

OECD, Stoke, W., Löwbeer, H., \& Capelle, J. (1966). Modernizing our schools. Curriculum improvement and educational development. Paris: OECD Publishing.

Parnes, H. S. (1962). Manpower analysis in educational planning. In OECD and H. S. Parnes (Eds.), The Mediterranean Regional Project. Planning education for economic and social development (pp. 73-84). Paris: OECD Publishing. 
Porter, T. M. (1995). Trust in numbers. The pursuit of objectivity in science and public life. Princeton, NJ: Princeton University Press.

Rickover, H. G. (1959). Education and freedom. New York, NY: E. P. Dutton

Rizvi, F., \& Lingard, B. (2006). Globalization and the changing nature of the OECD's educational work. In H. Lauder, P. Brown, \& J.-A. Dillabough, et al. (Eds.), Education, globalization, and social change (pp. 247-260). Oxford: Oxford University Press.

Rizvi, F., \& Lingard, B. (2010). Globalizing education policy. New York: Routledge.

Roberson, E. W. (1971). Educational accountability through evaluation. Englewood Cliffs, NJ: Educational Technology Publications.

Rudolph, J. (2002). Scientists in the classroom: The Cold War reconstruction of American science education. New York, NY: Palgrave Macmillan.

Sellar, S., \& Lingard, B. (2013). PISA and the expanding role of the OECD in global educational governance. In H. D. Meyer \& A. Benavot (Eds.), PISA, power and policy. The emergence of global educational governance (pp. 185-206). Oxford: Symposium Books.

Solovey, M. (2013). Shaky foundations: The politics-patronage-social science nexus in Cold War America. Newark, NJ: Rutgers University Press.

Thompson, E. P. (1963). The making of the English working class. London: Victor Gollancz.

Time Magazine (1957). Education: What price life adjustment? Time Magazine, December 2, LXX (23).

Tröhler, D. (2010). Harmonizing the educational globe. World polity, cultural features, and the challenges to educational research. Studies in Philosophy and Education, 29, 7-29.

Tröhler, D. (2011). The global language on education policy and prospects of education research. In D. Tröhler \& R. Barbu (Eds.), The future of education research. Research on educational systems: historical, cultural and sociological perspectives (pp. 55-73). Rotterdam, The Netherlands: Sense Publishers.

Tröhler, D. (2013). The OECD and Cold War culture: Thinking historically about PISA. In H.-D. Meyer \& A. Benavot (Eds.), PISA, power, and policy. The emergence of global educational governance (pp. 141-161). Oxford: Symposium Books.

Truman, H. S. (1947). Special message to the congress on Greece and Turkey. Retrieved from http:/ / www.presidency.ucsb.edu/ws/index.php?pid=12846

Urban, W. J. (2010). More than science and Sputnik: The National Defense Act of 1958. Tuscaloosa, AL: University of Alabama Press.

Vaizey, J. E. (1954). The cost of social services. London: Fabian Publications.

Vaizey, J. E. (1958). The costs of education. London: George Allen and Unwin.

Vaizey, J. E. (1961). Education as investment in comparative perspective. Comparative Education Review, 5, 97-104

Vaizey, J. E. (1962a). The economics of education. London: Faber \& Faber.

Vaizey, J. E. (1962b). The role of education in economic development. In OECD \& H. S. Parnes (Eds.), The Mediterranean Regional Project. Planning education for economic and social development (pp. 39-47). Paris: OECD Publishing.

Weymann, A., \& Martens, K. (2005). Bildungspolitik durch internationale Organisationen. Entwicklung, Strategien und Bedeutung der OECD. Österreichische Zeitschrift für Soziologie. 30(4), 68-86. 
DANIEL TRÖHLER is Professor of Education and Director of the Doctoral School in Educational Sciences at the University of Luxembourg and Visiting Professor of Comparative Education at the University of Granada, Spain. His latest publications include Languages of Education: Protestant Legacies, National Identities, and Global Aspirations (Routledge 2011) (AERA Outstanding Book of the Year Award) and Pestalozzi and the Educationalization of the World (Palgrave Pivot 2013). 